\title{
Sexual Behavior of Tribulus Terrestris
}

\author{
Mohammad Kamil $^{1 *}$, MT Abdallah ${ }^{2}$ and F Ahmad ${ }^{3}$ \\ ${ }^{1}$ Former Head TCAM Research, DOH, AD, UAE \\ ${ }^{2}$ Former Research Assistant TCAM Research, DOH, AD, UAE \\ ${ }^{3}$ Former Research Assistant TCAM Research, DOH, AD, UAE \\ *Corresponding author: Mohammad Kamil, Former Head TCAM Research, DOH,AD, UAE
}

\begin{tabular}{|c|c|}
\hline ARTICLE INFO & ABSTRACT \\
\hline 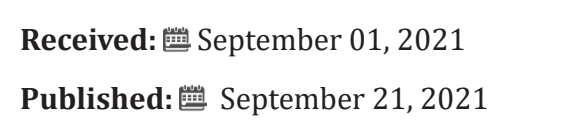 & $\begin{array}{l}\text { Abbreviations: TLC: Thin Layer Chromatography; BP: Blood Pressure; STT: Saponins } \\
\text { from Tribulus Terrestris; MSH: Melanocyte Stimulating Hormone }\end{array}$ \\
\hline $\begin{array}{l}\text { Citation: Mohammad Kamil, MT Abdal- } \\
\text { lah, F Ahmad. Sexual Behavior of Tribulus } \\
\text { Terrestris. Biomed J Sci \& Tech Res 38(5)- } \\
\text { 2021. BJSTR. MS.ID.006220. }\end{array}$ & \\
\hline
\end{tabular}

\section{Introduction}

Many of today's popular dietary supplements come from plants that have been used medicinally since ancient times. One of these botanicals is Tribulus terrestris, which is purported to have a variety of health benefits, including reduced blood sugar, cholesterol, altered hormone levels and increased sexual function and libido. Tribulus terrestris is normally distributed in tropical and subtropical countries in Asia, Africa, south Europe, North Australia and introduced in new world tropics. In UAE common and widespread in Urban areas, roadsides and depressions receiving runoff water

(Figure 1) [1]. In UAE the plant is used by some healers as an aphrodisiac, diuretic and hypotensive also used to treat dysuria; it is soothing, analgesic, diuretic, tonic, against colic . The leaves of the plant used to treat enlarged spleen, puerperal fever, sores, diarrhea, nervous exhaustion and cramps, normally the whole plant is used. A transverse section of the stem from the periphery to the pith shows the following: an epidermal layer consisting of small ovoid cells with thick cell walls and the epidermis is covered with thick cuticle.

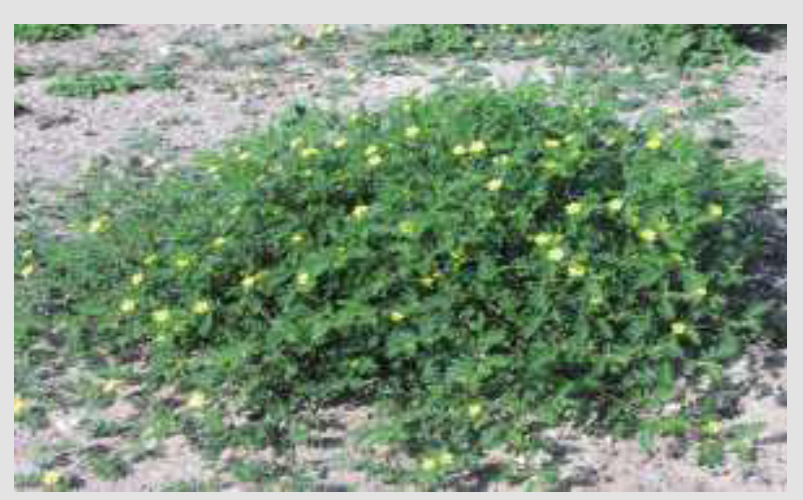

Figure 1: Tribulus Terrestris. 
Attached to the epidermis are numerous one-celled covering trichomes that have comparatively wide lumens and thick cell walls. The epidermis is encircling several layer of cortical colenchyma (about 6-7 layers); the inner layers enclose groups of lignified fibres that have thick cell walls and narrow lumens. The cortex encircles phloem tissues, heavily lignified xylem tissues (vessels, trachieds and fibres) and at the centre are the nearly rounded parenchyma cells of the pith which occupy a wide zone (Figure 2).
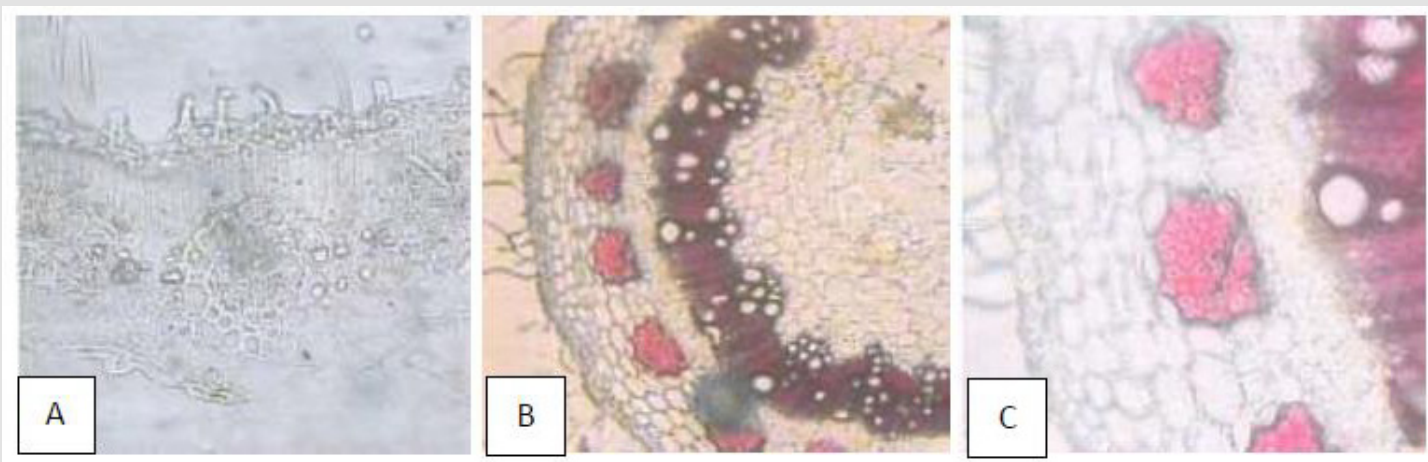

Figure 2:

a) Leaf: Detailed transverse section at the midrib region covering and glandular trichomes on the upper epidermis, palisade (one layer) spongy tissues, vascular tissues, lower epidermis (less covering trichomes) coloured particles (in palisade and spongy parenchyma cells). Vascular elements are surrounded by characteristic cells with thick cell walls and wide lumen.

b) From outside to inside (TS of stem): Covering trichomes, epidermal layer (small globular cells covered with a thick cuticle), several layers of cortical collenchyma, groups of lignified fibres of the cortex (purple in colour), phloem tissues, heavily lignified xylem tissues (vessels, tracheids, fibres (dark violet) and at the centre the parenchyma cells of the pith.

c) From outside to inside (TS of stem): Epidermal layer (small ovoid cells with thick cell walls) bearing covering trichomes, cortical collenchyma with thick cells, groups of lignified fibres with thick cell walls and narrow lumens, phloem tissues, vessels, tracheids and xylem fibres (heavily lignified).

\section{Chemical Constituents}

Alkaloids, fixed and volatile oils, saponins diasogenin, ruscogenin, resin and sapogenin [2]. Compounds: terrestribisamide, 25R-spirost-4-en-3,12-dione and tribulusterine. N-p-coumaroyltyramine, terrestriamide, hecogenin, aurantiamide acetate, xanthosine, fatty acid ester, ferulic acid, vanillin, p-hydroxybenzoic acid and $\beta$-sitosterol in dried fruits [3]. The steroidal saponins: protodioscin, prototribestin, pseudoprotodioscin, dioscin, tribestin and tribulosin. The flavonoid rutin. Furostanol saponin (tribol), and sitosterol glucoside [4]. furostanol saponins from the fruits : terrestroside A [5]. Furostanol glycosides: tribufurosides I and J from the fruits [6]. sitosterol-D-glucoside and a spirostanol type steroidal saponins: Tribulosin [7]. also contains the steroidal saponin: protodioscin [8]. Steroidal saponins in the aerial parts : Protodioscin, neoprotodioscin and prototribestin [9]. Aerial parts: flavonoids, tannins,sterols and/or triterpens and volatile oils. leaves and fruits: flavonoids kampferol, kamferl 3-glucoside, kaempferol 3-rutino-side and tribloside.

Steroidal saponins diosgenin. Chlorogenin and gitogenin, ruscogenin, hecogenin, neotigogenin, and 3-deoxy $\Delta^{3}$-diosgenin, $\beta$ - sitosterol and stigmasterol. Steroid glycoside dioscin, trillin,
diosgenin-Dglycoside and gracillin in addition to Harman and harmine alkaloids from the aerial parts. The flowers contain sterols (stigmasterol, campesterol and $\beta$-sitosterol), sapogenins (diosgenin, gitogenin, neogitogenin), flavonoidal aglycons (Kaempferol, quercetin) and reducing sugars (D-glucose, D-arabinose and L-rhamnose).The aerial parts contain steroidal saponins main furostanol bisglycosides [10].

\section{Physicochemical Constituents (\%)}

Physico chemical constituents carried out on the plant Tribuls terrestris are as follows:

\section{$>\quad$ Loss of weight in drying at $105^{\circ} \mathrm{C}: 7.09$}

Absolute alcohol solubility

Water solubility

\section{$>\quad$ Successive extractives $(\%)$}

Petroleum ether $\left(60-80^{\circ} \mathrm{C}\right)$

Chloroform

$>$ Absolute alcohol

Distilled water

$: 18.00$ 
$>\quad$ Ash values (\%)

Total ash

Water soluble ash

Acid insoluble ash $(10 \% \mathrm{HCl})$
$: 10.60$

$: 3.60$

$: 1.30$

\section{pH values (aqueous solution)}

$\mathrm{pH}$ of $1 \%$ solution

: 5.98-6.05

$\mathrm{pH}$ of $10 \%$ solution

\section{Elemental Analyses}

(Table 1).

Table 1.

\begin{tabular}{|c|c|c|c|c|c|}
\hline \multicolumn{6}{|c|}{ Ash values ( British Herbal Pharmacopeia- Reference) } \\
\hline \multicolumn{6}{|c|}{ Assay and identification of element (AOAC International-Reference) } \\
\hline \multirow{2}{*}{$\begin{array}{c}\text { Apparatus } \\
\text { Element }\end{array}$} & \multicolumn{5}{|c|}{ (AA-6800 Shimadzu-Flame method) } \\
\hline & Std. conc. $\mu \mathrm{g} / \mathrm{ml}(\mathrm{ppm})$ & Sample conc.mg/ml & Sample absorbance & Actual conc.mg/ml & Actual conc. (\%) \\
\hline $\mathrm{Cr}$ & $1,2,4$ & 10 & 0.0005 & 0.00081 & 0.000081 \\
\hline $\mathrm{Zn}$ & $0.25,0.5,1$ & 10 & 0.1489 & 0.04472 & 0.004472 \\
\hline $\mathrm{Cu}$ & $1,2,4$ & 10 & 0.0148 & 0.0178 & 0.00178 \\
\hline $\mathrm{Fe}$ & $1,2,4$ & 0.909 & 0.2053 & 0.38748 & 0.038748 \\
\hline $\mathrm{K}$ & $1,2,4$ & 0.909 & 1.0576 & 8.6685 & 0.86685 \\
\hline $\mathrm{Pb}$ & $1,2,4$ & 10 & 0.0000 & $<0.01 \mu \mathrm{g} / \mathrm{g}$ & 0.0000 \\
\hline $\mathrm{Cd}$ & $0.125,0.25,0.5$ & 10 & 0.0000 & $<0.001 \mu \mathrm{g} / \mathrm{g}$ & 0.0000 \\
\hline $\mathrm{Ca}$ & $5,10,20$ & 0.0826 & 0.1130 & 26.937 & 2.6937 \\
\hline $\mathrm{Mg}$ & $0.25,0.5,1$ & 0.0826 & 1.0394 & 10.7003 & 1.07003 \\
\hline $\mathrm{Na}$ & $1,2,4$ & 0.909 & 0.1242 & 2.84108 & 0.284108 \\
\hline
\end{tabular}

\section{UV Spectral Studies}

(Table 2, Figures $3 \& 4$ ).

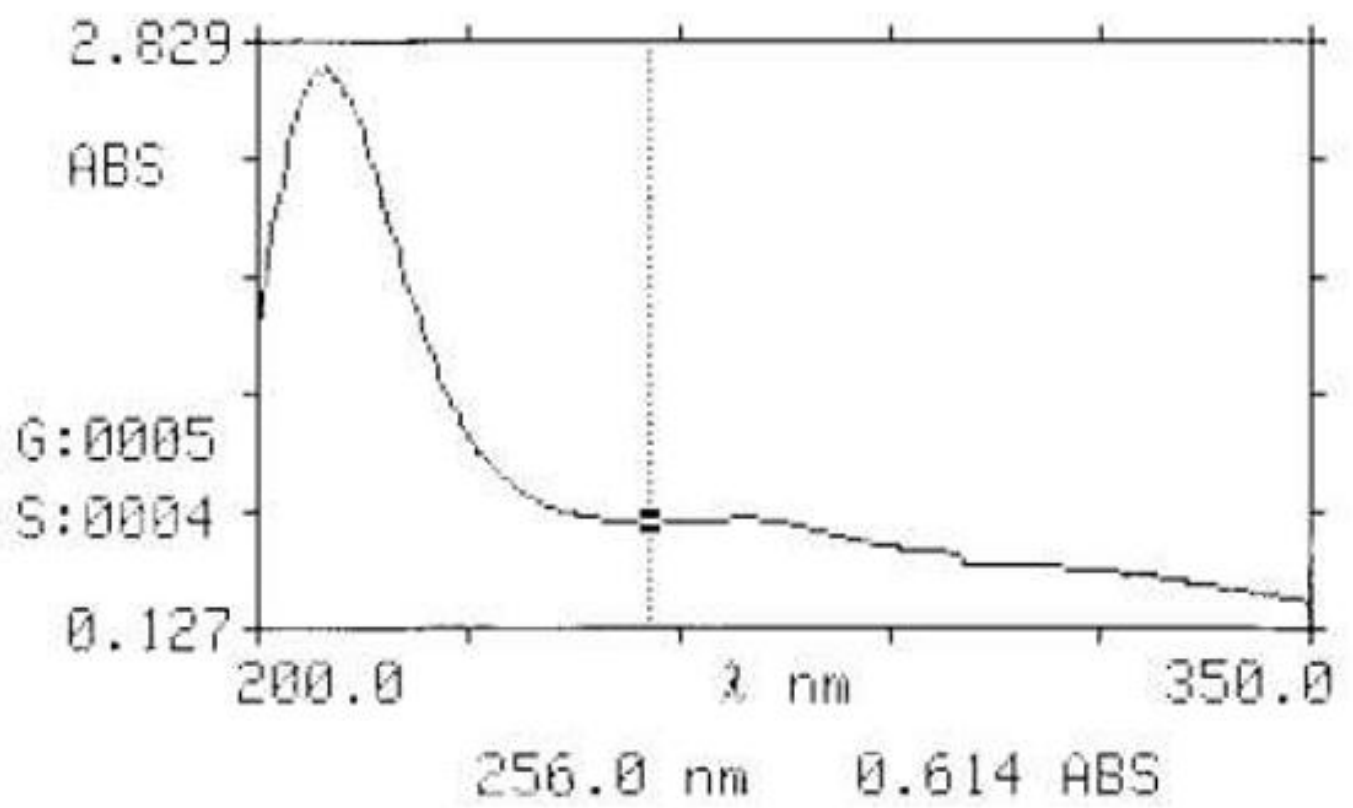

Figure 3: Intestinal Fluid simulated without pancreatic $\mathrm{pH}=7.5 \pm 0.1$. 


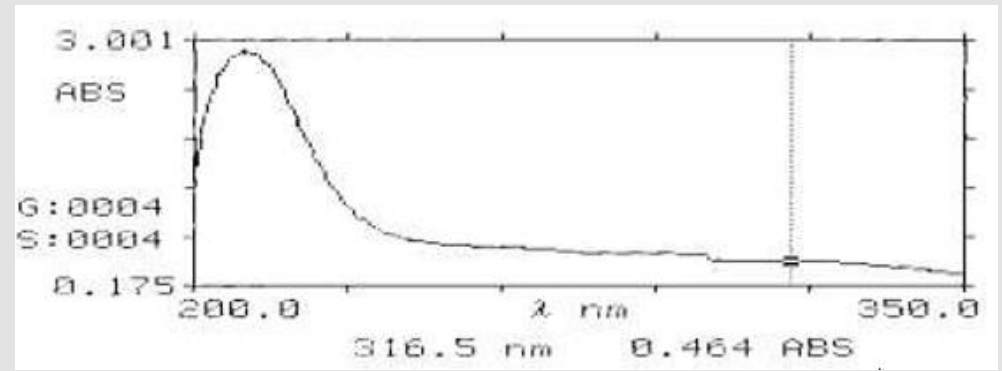

Figure 4: Gastric Fluid simulated without pepsin $\mathrm{pH}=1.2 \pm 0.1$.

Table 2.

\begin{tabular}{|c|c|c|c|c|}
\hline \multicolumn{5}{|c|}{ Ultraviolet Spectrum (USP reference) } \\
\hline Apparatus & \multicolumn{4}{|c|}{ Beckman DU 520 general purpose UV/VIS spectrophotometer } \\
\hline Sample conc. ( $\mathrm{mg} / \mathrm{ml})$ & Solvent & $\lambda \max (\mathrm{nm})$ & $\lambda \min (\mathrm{nm})$ & Abs. $(\lambda \max -\lambda \min )$ \\
\hline \multirow{2}{*}{0.529} & Intestinal Fluid simulated without & 210.5 & & 2.693 \\
\hline & pancreatic $\mathrm{pH}=7.5 \pm 0.1$ & 269 & 256 & $0.635-0.614$ \\
\hline \multirow{10}{*}{0.875} & Gastric Fluid simulated without & 316.5 & 312.5 & $0.464-0.466$ \\
\hline & pepsin $\mathrm{pH}=1.2 \pm 0.1$ & 313 & 310 & $0.467-0.466$ \\
\hline & & 309.5 & 305.5 & $0.467-0.466$ \\
\hline & & 307.5 & 304 & $0.467-0.466$ \\
\hline & & 304.5 & 301.5 & 0.468 \\
\hline & & 302 & 284 & $0.469-0.469$ \\
\hline & & 286.5 & 282 & $0.551-0.550$ \\
\hline & & 283.5 & 279 & $0.551-0.551$ \\
\hline & & 281 & & $0.551-0.550$ \\
\hline & & 210 & & 2.87 \\
\hline
\end{tabular}

\section{Thin layer Chromatography (TLC)}

Figure 5.

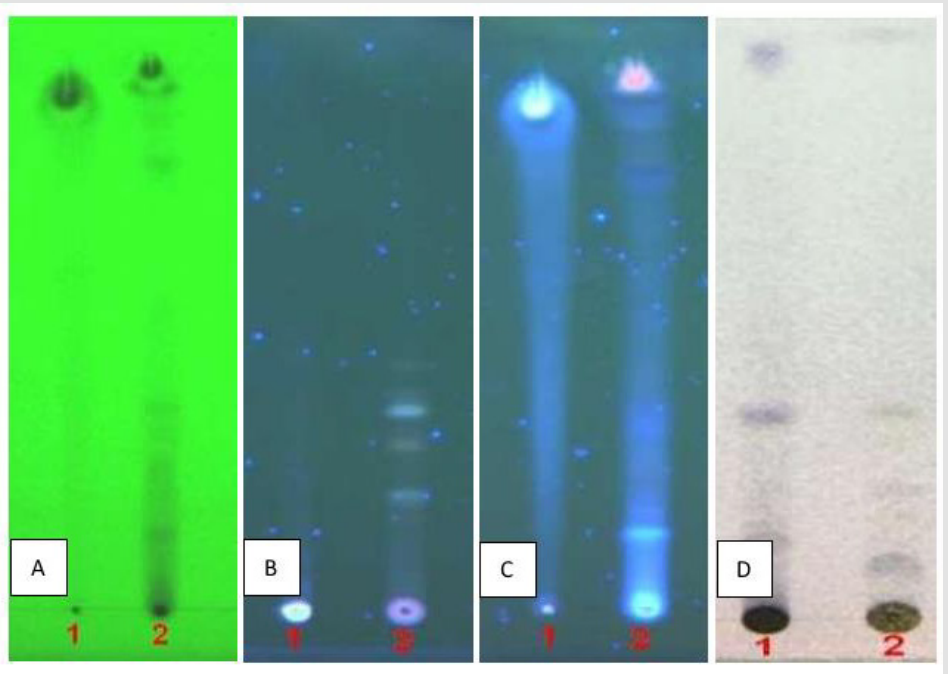

Figure 5: TLC fingerprint of Petroleum ether -60-800 (track 1) and MeOH extract (track 2) Mobile phase.

- A\&C: Ethyl acetate, methanol, water (100:13.5:10).

- B\&D: Toluene, ethyl acetate (93:7)

- Detection A: UV 254nm

- B\&C: UV366nm

- Derivatization D: Vanillin- Sulphuric acid-vis. 


\section{Pharmacological and Toxicological Studies}

Information reported in the Literature about the plant: The important pharmacological and toxicological activities of the plant Tribulus terrestris reported in various scientific journals have been presented in the present brief review: A mixture of 9 oriental herbs were given including Tribulus terrestris showed an increase in the copulatory behavior parameters in rats, improved the sexual activity and erectile function. The effects of methanolic and aqueous extracts of Tribulus terrestris on rat blood pressure (BP) and the perfusion of mesenteric vascular bed were investigated and found possessing significant antihypertensive activity in spontaneously hypertensive rats [11]. Effect of Saponins from Tribulus terrestris (STT) on the renal carcinoma cell (786-0) in vitro and inhibitory mechanisms studied significantly inhibited the growth of 786-0 in vitro, partially, by apoptosis [12]. Tribulus is a genus of plants found in many warm regions.

The best-known member is T. terrestris (Puncture Vine), a widespread weed and also the source of a dietary supplement claimed to increase the body's natural testosterone levels and thereby improve male sexual performance and help build muscle. T. terrestris has consistently failed to increase testosterone levels in controlled studies [13-15]. It has also failed to demonstrate strength-enhancing properties [16]. Tribulus has been shown to enhance sexual behaviour in an animal model. It appears to do so by stimulating androgen receptors in the brain [17]. Jameel, et al. [18] reported a case of a young weight-trainer who developed gynaecomastia due to oral intake of an herbal tablet which he used as a steroid alternative for body-building. The aqueous extract of Tribulus terrestris can significantly increase melanocyte-stimulating hormone (MSH) expression in the hair follicle melanocytes by activating tyrosinase activity and promoting melanocyte proliferation, melanine synthesis, and epidermal migration of dormant melanocytes [19]. Tribulus terrestris showed protective effect for STZ-induced diabetic rats may be mediated by inhibiting oxidative stress [20].

Sharif, et al. [21] investigated the antihypertensive mechanism of Tribulus in 2K1C hypertensive rats by measurement of circulatory and local ACE activity in aorta, heart, kidney and lung. The ACE activity in all tissues of Tribulus fed hypertensive rats was significantly lower than that of hypertensive rats, which was more pronounced in kidney. These results indicated that there is a negative correlation between consumption of Tribulus and ACE activity in serum and different tissues in $2 \mathrm{~K} 1 \mathrm{C}$ rats. Oludotun, et al. [22] reported the effects of methanolic and aqueous extracts of Tribulus terrestris on rat blood pressure (BP) and the perfused mesenteric vascular bed were investigated. The extracts dosedependently reduced BP in spontaneously hypertensive rats (SHRs) with the aqueous fraction being more potent than the methanolic fraction at all doses tested. In vitro, the methanolic but not aqueous extract produced a dose-dependent increase in perfusion pressure of the mesenteric vascular bed. When perfusion pressure was raised with phenylephrine, the aqueous extract produced a dosedependent reduction in perfusion. It was concluded that methanolic and aqueous extracts of Tribulus terrestris possess significant antihypertensive activity in spontaneously hypertensive rats.

The antihypertensive effects appeared to result from a direct arterial smooth muscle relaxation possibly involving nitric oxide release and membrane hyperpolarization. The inhibitory effect of saponins from Tribulus terrestris (STT) on Bcap-37 breast cancer cell line were determined by cell growth curve, MTT assay, protein content assay and morphological observation showed that STT had potent inhibitory effect on Bcap-37 cell line in a concentrationdependent manner [23]. The results of pharmacological and Toxicological studies carried on the $70 \%$ alcoholic extract of the plant, have been given below (Figures 6-8 and Table 3).

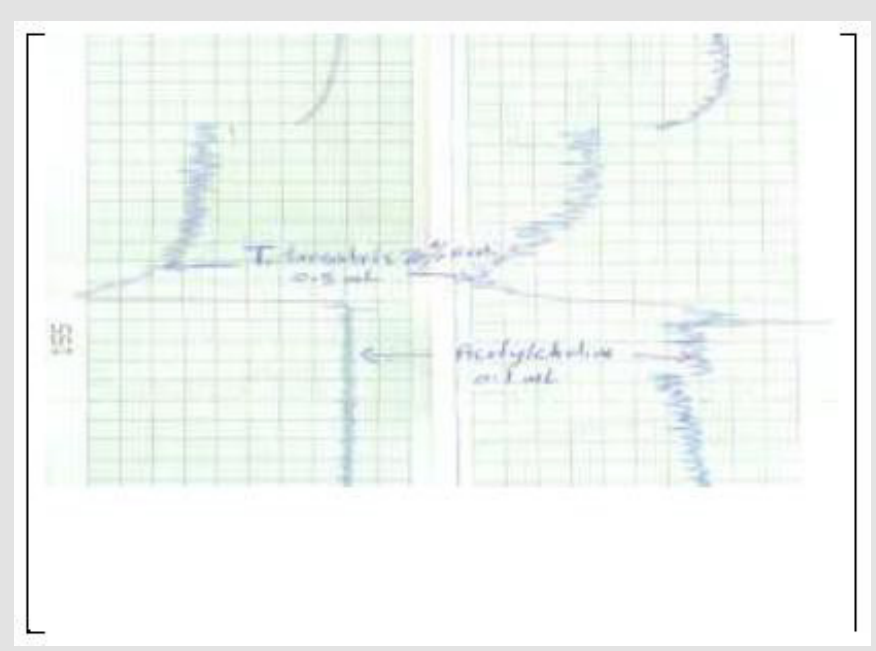

Figure 6: Effect of Tribulus t. on rat detrusor muscle acetylcholine treated. 


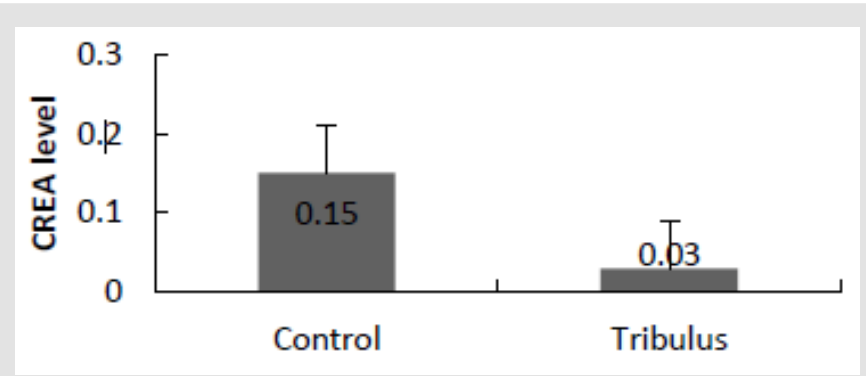

Figure 7: Effect of Tibulus 70\% ethanol extract on serum createnin level.

Table 3.

\begin{tabular}{|c|c|c|c|c|}
\hline \multirow{2}{*}{ Activity } & \multicolumn{4}{|c|}{ Results } \\
\hline & Strong & Moderate & Mild & Negative \\
\hline Anti-inflammatory (Ear edema) & & & & $\sqrt{ }$ \\
\hline Anti-diabetic activity (STZ) & & & $\sqrt{ }$ & \\
\hline Antidepressant & & & $\sqrt{ }$ & \\
\hline Anticonvulsant & & & & $\sqrt{ }$ \\
\hline Effect on mesenteric artery & & $\sqrt{ }$ & & \\
\hline Endocrinological studied & & & & $\sqrt{ }$ \\
\hline Effect on Guinea pig ileum & & $\sqrt{ }$ & & \\
\hline Rat detrusor muscle & & $\sqrt{ }$ & & \\
\hline Effect on corpus cavernous strip & & & $\sqrt{ }$ & \\
\hline Antithrombotic activity & & & & $\sqrt{ }$ \\
\hline Acute toxicity on mice & & & & $\sqrt{ }$ \\
\hline Biochemical studies & & & & $\sqrt{ }$ \\
\hline Hematological studies (MCH \& PLT) & & $\sqrt{ }$ & & \\
\hline Effect on kidneys weight & & $\sqrt{ }$ & & \\
\hline Locomotor activity test & & & & $\sqrt{ }$ \\
\hline Motor co-ordination (Rota rod test) & & & & $\sqrt{ }$ \\
\hline Rectal temperature & & & & $\sqrt{ }$ \\
\hline Body weight & & & & $\sqrt{ }$ \\
\hline Mortality & & & & $\sqrt{ }$ \\
\hline $\mathrm{LD} 50=>10 \mathrm{~g} / \mathrm{kg}$ p.o. in mice & & & & \\
\hline
\end{tabular}

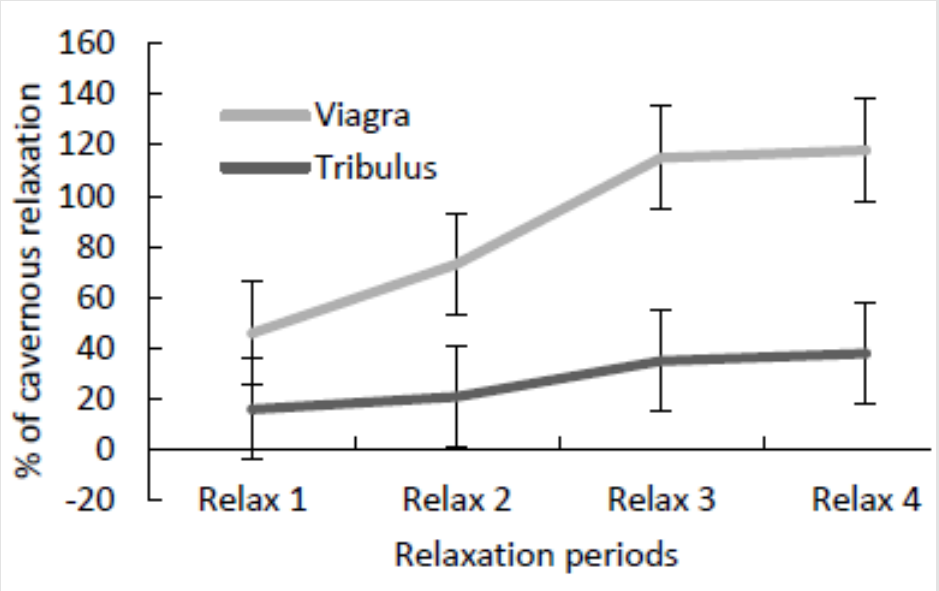

Figure 8: Tribulus Sexual study followed by Viagra. 


\section{Conclusion}

The oral administration of the plant extract was non-toxic up to the dose of $10 \mathrm{~g} / \mathrm{kg}$ b.wt., p.o. These acute studies demonstrated that the plant extract is safe and did not cause any detrimental effects in vivo under the conditions investigated in this study. The LD50 of plant extract was found to be $>10 \mathrm{~g} / \mathrm{kg}$ when administered once via gastric intubation to rats. Plant extract produced a mild relaxation in phenylephrine pre-contracted corpus cavernous tissue.

\section{References}

1. Mandaville JP (1990) Flora of Eastern Saudi Arabia Riyadh, Saudi Arabia: Kegan Paul International.

2. El-Ghonemy AA (1993) Encyclopedia of Medicinal Plants of the United Arab Emirates (1 ${ }^{\text {st }}$ Edn.). University of UAE.

3. Tian-Shung W, Li-Shian S, Shang-Chu K (1999) Alkaloids and other constituents from Tribulus Terrestris. Phytochemistry 50: 1411-1415.

4. Conrad J, Dinchev D, Klaiber I, Mika SI, Kostova I, et al. (2004) A novel furostanol saponin from Tribulus terrestris of Bulgarian origin. Fitoterapia 75(2): 117-122.

5. Wei-Hua Y, Nai-Li W, Yang-Hua Y, Yao Xin-Sheng Y (2008) Two Furostanol Saponins from the Fruits of Tribulus Terrestris. Chinese Journal of Natural Medicines 6(3): 172-175.

6. Tunhai X, Yajuan X, Yue L, Shengxu X, Yunshan S, et al. (2009) Two new furostanol saponins from Tribulus Terrestris L. Fitoterapia 80: 354-357.

7. Deepak M, Dipankar G, Prashanth D, Asha MK, Amit A, et al. (2002) Tribulosin and b-sitosterol-D-glucoside, the anthelmintic principles of Tribulus Terrestris. Phytomedicine 9: 753-756.

8. Gauthaman KPG, Adaikan PG, Prasad RNV (2002) Aphrodisiac properties of Tribulus terrestris extract (Protodioscin) in normal and castrated rats. Life Sciences 71: 1385-1396.

9. De Combarieu E, Fuzzati N, Lovati M, Mercalli E (2003) Furostanol saponins from Tribulus terrestris. Fitoterapia 74: 583-591.

10. Al-Yahya MA, Al-Meshal IA, Mossa JS, Al-Badr AA, Tariq M (1990) Saudi Plants: A Phytochemical and Biological Approach. King Abdul Aziz City for Sciences.

11. Phillips OA, Mathew KT, Oriowo MA (2006) Antihypertensive and vasodilator effects of methanolic and aqueous extracts of Tribulus terrestris in rats. J Ethnopharmacol 104(3): 351-355.

\section{ISSN: 2574-1241}

DOI: 10.26717/BJSTR.2021.38.006220

Mohammad Kamil. Biomed J Sci \& Tech Res

(C) (P) This work is licensed under Creative

Submission Link: https://biomedres.us/submit-manuscript.php
12. Yang HJ, Qu WJ, Sun B (2005) Experimental study of saponins from Tribulus terrestris on renal carcinoma cell line. Zhongguo Zhong Yao Za Zhi 30(16): 1271-1274.

13. Brown GA, Vukovich MD, Martini ER, Kohut ML, Franke WD, et al (2001) Endocrine and lipid responses to chronic androstenediol-herbal supplementation in 30 to 58 year old men. J Am CollNutr 20(5): 520528.

14. Brown GA, Vukovich MD, Reifenrath TA, Uhl NL, Parsons KA, et al. (2000) Effects of anabolic precursors on serum testosterone concentrations and adaptations to resistance training in young men. Int J Sport Nutr Exerc Metab 10(3): 340-359.

15. Neychev VK, Mitev VI (2005) The aphrodisiac herb Tribulus Terrestris does not influence the androgen production in young men. J Ethnopharmacol 101 (1-3): 319-323.

16. Rogerson S, Riches CJ, Jennings C, Weather by RP, Meir RA, et al. (2007) The Effect of Five Weeks of Tribulus terrestris Supplementation on Muscle Strength and Body Composition During Preseason Training in Elite Rugby League Players. J Strength Cond Res 21(2): 348- 353.

17. Gauthaman K, Adaikan PG, Prasad RNV (2002) Aphrodisiac properties of Tribulus terrestris extract (Protodioscin) in normal and castrated rats. Life Sciences 71: 1385-1396.

18. Jameel JK, Kneeshaw PJ, Rao VS, Drew PJ (2004) Gynaecomastia and the plant product "Tribulus terrestris". Breast 13(5): 428-430.

19. Yang L, Lu JW, An J, Jiang X (2006) Effect of Tribulus terrestris extract on melanocyte- stimulating hormone expression in mouse hair follicles. Nan Fang Yi Ke Da Xue Xue Bao 26(12): 1777-1779.

20. Amin A, Lotfy M, Shafiullah M, Adeghate E (2006) The protective effect of Tribulus terrestris in diabetes. Ann NY Acad Sci Nov 1084: 391-401.

21. Sharifi AM, Darabi R, Akbarloo N (2003) Study of antihypertensive mechanism of Tribulus terrestris in 2K1C hypertensive rats, role of tissue ACE activity. Life Sci 73(23): 2963-2971.

22. Oludotun A, Phillips Koyippalli T, Mathew Mabayoje A, Oriowo (2006) Antihypertensive and vasodilator effects of methanolic and aqueous extracts of Tribulus terrestris in rats. J Ethnopharmacol 104: 351-355.

23. Sun B, Qu W, Bai Z (2003) The inhibitory effect of saponins from Tribulus terrestris on Bcap-37 breast cancer cell line in vitro. Zhong Yao Cai 26(2): 104-106.

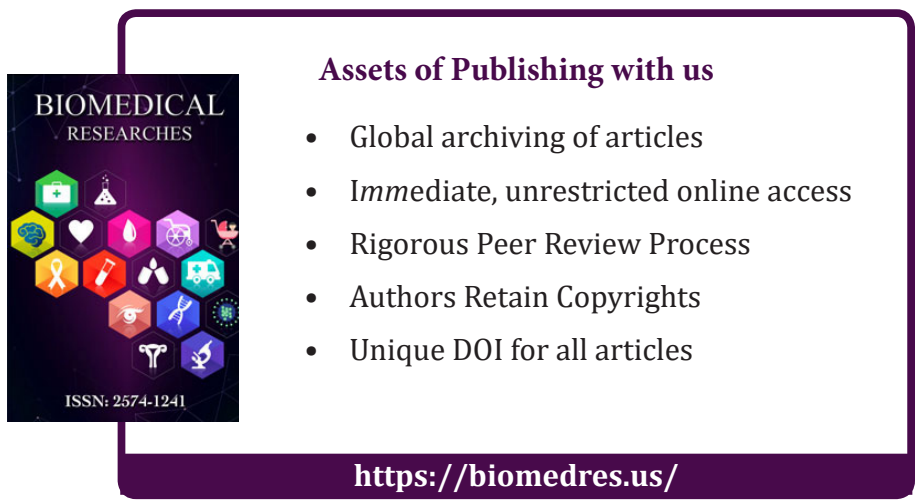

Copyright@ Mohammad Kamil | Biomed J Sci \& Tech Res | BJSTR. MS.ID.006220. 